\title{
Notional Defined Contribution (NDC) Schemes: A Pension System Alternative
}

\author{
Gustavo da Costa Morais ${ }^{1}$ - Universidade Federal Fluminense, Brazil \\ Carolina Cardoso Novo² - Universidade Federal Fluminense, Brazil \\ Mirian Picinini Méxas ${ }^{3}$ - Universidade Federal Fluminense, Brazil
}

This article aims to discuss the main concepts related to notional defined contribution (NDC) schemes and to analyze the experiences of Sweden, Italy, Latvia, Poland and Norway. The methodology is based on a literature review. The main result was that the extent of NDC as a pension system alternative depends on the degree of closeness to the generic scheme. It is recommended to analyze NDC as an alternative for pension system reforms considering its capacity to control structural deficits. As a limitation, it was not analyzed some possible social impacts of NDC introduction. This article is original because encompasses theoretical and practical aspects of NDC schemes. It is expected that this research can contribute to assist public officials in decision-making about reforms in pension systems.

JEL Classification: $H 55$

Keywords: notional defined contribution schemes, generic NDC scheme, pension systems

\section{Modelos de Contribución Definida Nocional (CDN): una alternativa a los sistemas de pensiones}

Este artículo tiene como objetivo discutir los principales conceptos relacionados con los modelos de contribución definida nocional (CDN) y analizar las experiencias de Suecia, Italia, Letonia, Polonia y Noruega. La metodología se basa en una revisión de la literatura. El principal resultado encontrado fue que la extensión de los modelos CDN como alternativa a los sistemas de pensiones depende del grado de proximidad al modelo genérico. Se recomienda analizar el modelo CDN como una alternativa para las reformas de los sistemas de pensiones considerando su capacidad para controlar los déficits estructurales. Como limitación, no se analizaron los posibles impactos sociales de la introducción de estos modelos. Este artículo es original porque cubre aspectos teóricos y prácticos de los modelos CDN. Se espera que este trabajo pueda contribuir a ayudar a los administradores públicos a tomar decisiones sobre reformas en los sistemas de pensiones.

Clasificación JEL: H55

Palabras clave: modelos de contribución definida nocional, modelo CDN genérico, sistemas de pensiones

${ }^{1}$ Corresponding author. ORCID: https://orcid.org/0000-0002-8693-1329; Email: gustavomorais@id.uff.br

2 ORCID: https://orcid.org/0000-0002-3186-275X

3 ORCID: https://orcid.org/0000-0003-4506-7009

* No source of funding for research development 


\section{Introduction}

According to Holzmann (2017), the need for reforms in pension systems is an issue that arises in the Organization for Economic Cooperation and Development (OECD) countries with the economic boom interruption after Second World War, caused by the first oil price shock in the 1970s and changes in demographic structures, after the introduction of this systems in the 1950s and their expansion in the 1960s.

The 1980s were characterized by the search for internal solutions that address short-term pension systems financing gaps and long-term demographic challenges, given the transition to lower fertility rates. However, these reforms discourse was limited to interventions into parametric adjustments, such as reductions in retirement benefit levels and an increase in contribution rates.

A more systemic reform vision was manifested internationally in 1981 by Chile, a pioneer country to introduce funded pension schemes, with a gradual constitution of reserves invested in the financial market (Corrêa, 2018). However, the adoption of funded pension schemes can impose serious challenges on countries, such as the creation of a favourable environment to financial market development, the expected level of financial market returns and the ability to finance transition deficits.

Considering these challenges, Sweden, in a pioneering way, developed in 1994 a reform concept that structurally modified its old pension system. The reform introduced a scheme that had never been adopted in the world: the notional defined contribution (NDC) scheme, which was later implemented in other countries such as Italy (Franco and Sartor, 2006), Latvia (Palmer et al., 2006), Poland (Chłoń-Domińczak and Góra, 2006) and Norway (Christensen et al., 2012).

In order to contribute to pension system reforms discussion, it was found that NDC is a defined contribution pay-as-you-go (PAYG) scheme, classified as quasi-actuarial. This implies that the retirement benefits have a direct correspondence with the contributions made over the individual's working life, and these benefits are financed by contributions from the active population. Contributions, in turn, form an individual account only for accounting purposes, so that deposits in this account are not invested in the financial market.

These characteristics associated with the reserve fund, a fund that collects and disburses resources from demographic fluctuations and the Automatic Balancing Mechanism (ABM), a mechanism that automatically decreases the internal rate of return in deficit situations, make NDC scheme an alternative to promote system financial balance.

\section{Methodology}

This article proposes a literature review to identify and discuss the fundamental aspects of NDC schemes and to analyze the experiences of Sweden, Italy, Latvia, Poland and Norway.

Initially, some key expressions were defined for the searches such as "notional defined contribution", "nonfinancial defined contribution" and "non-financial defined contribution" with emphasis on the title of the publications. 
As a result, the methodology for the theoretical aspects of NDC schemes was based on Palmer (2000, 2006), Settergren (2001), Settergren and Mikula (2006) and Serrano (2015) and the methodology to analyse the experiences of Sweden, Italy, Latvia, Poland and Norway was based on Könberg, Palmer and Sundén (2006), Franco and Sartor (2006), Palmer et al. (2006), ChłońDomińczak and Góra (2006), Chłoń-Domińczak, Franco and Palmer (2012) and Christensen et al. (2012), with some complementary works.

\section{Origin of NDC schemes}

The first ideas related to NDC schemes originate in conceptions exposed by Buchanan (1968) in his article "Social Insurance in a Growing Economy: A Proposal for Radical Reform", published in the National Tax Journal (Valdés-Prieto, 2000; Palmer, 2006).

Buchanan (1968) had proposed to the United States a pension scheme that encompassed three main characteristics: the acquisition of individualized rights to enabling retirement benefits, based on individual earnings; the individual's right to leave the government system and opt for private insurance; and the replacement of payroll taxes by an individual and mandatory purchase of a new type of bond, called Social Insurance Bonds, whose yield would result from the higher value between the rate of return on long-term U.S. Treasury bonds and the rate of growth in Gross National Product (GNP).

Retirement benefits would come from converting the total amount obtained in Social Insurance Bonds maturity into a lifetime annuity that would guarantee the flow of benefit payments to individuals from the age of 65 years.

Revenues from Social Insurance Bonds sales, not in a mandatory way, could defray current retirement benefit expenses, insofar as general government revenues would cover any financing deficits. It should also be noted that the estimated sum of Social Insurance Bonds acquired by individuals during working life would be sufficient to finance their retirement benefits.

Afterwards, Boskin, Kotlikoff and Shoven (1985) also suggested a new pension scheme for the United States, in which each individual would have a Personal Security Account (PSA), an exclusive account where the contributions would be deposited.

Based on the total amount accumulated in these accounts, four types of annuities could be obtained, according to individuals needs: The Old Age Annuity, Spouse's Survival Annuity, Child Survival Annuity and Disability Annuity.

An Independent Actuary Council would determine the rate of return used in annuity calculations, to guarantee long-term balance between benefits and contributions, in an extension of 75 years, through demographic and economic projections.

PSA scheme would be a PAYG scheme, financed by contributions of the active population. However, differently from traditional PAYG schemes, PSA scheme would have a buffer fund mechanism to avoid short-term financing crises.

Another dimension of NDC schemes origin can be identified in Valdés-Prieto (2000). According to the author, notional accounts are an old concept, dating from at least 1945, with the introduction of the points system in France. 
According to this system, annual pension contributions provided "points" to individuals, which had a specific price at the time they were purchased. At retirement age, total points sum were converted into a benefit quantified in francs and indexed to inflation.

Annually, national councils discreetly defined three parameters: (1) the points purchase price, (2) the contribution rates and (3) the value of the points at the time they were sold to obtain the retirement benefit. However, the fact that such parametric adjustments were not based on longterm cash flow projections mischaracterized the approximation with the NDC concept.

Similar to the French points system, the German points system introduced in 1992 had a tenor of NDC schemes, according to Valdés-Prieto (2000). Each individual also accumulated points for retirement. At retirement age, the individual added up the points purchased over time to determine the initial retirement benefit as a proportion of the national average wage.

Based on the arguments described above, according to Palmer (2006), it is safe to state that NDC schemes emerged because of the sharing of ideas and discussions between experts and politicians who focused on issues related to pension reforms in countries in which this scheme was implemented. Thus, it is deduced that the series of reforms that redesigned pension systems in Europe in the 1990s contributed to materialise the idea of NDC schemes, as they are currently known.

\section{Definition and Classification of NDC schemes}

Palmer (2006), one of the experts that helped the Swedish pension system restructuring in the 1990s, defines NDC as defined contribution PAYG schemes. In other words, in NDC schemes, retirement benefits are associated with the contributions made over the individual's working life, which characterizes the defined contribution; and these benefits are financed by contributions from the active population, which represents the PAYG aspect.

In NDC schemes, the contributions based on individual wages form an individual account only for accounting purposes, for this reason, the term "notional". The deposits in that account are not invested in the financial market, such as in funded schemes. The rate of return applied to the notional accounts comes from an internal rate of return determined by factors related to the development of the economy.

Retirement benefits are lifetime annuities, resulting from the ratio between the total amount in the notional account and the annuity factor, which have the average life expectancy at individual retirement age and the internal rate of return as its components.

Furthermore, NDC schemes allow to convert these benefits into notional account and vice versa at any time after retirement begins; it is also possible to guarantee partial benefits (applying a percentage, for example), combining employment and retirement in any proportion, as well as to allow gradual exit from the labour market.

It is common to make distinction only between defined benefit (DB) schemes and defined contribution (DC) schemes when comparing different pension schemes. However, Lindbeck and Persson (2003) proposed a three-dimensional classification that incorporates characteristics such as the degree of funding and the degree of actuarial fairness. 
The first dimension of this classification differentiates defined contribution schemes from defined benefit schemes. In DC schemes, contribution rates are exogenous, while retirement benefits are endogenous, that is, as contribution rates are fixed, retirement benefits are adjusted periodically to ensure pension system financial balance (Lindbeck, 2006).

On the other hand, in DB schemes, the contribution rates on individual wages are endogenous, that is, they must be adjusted periodically to guarantee system financial balance and the payment of retirement benefits. Retirement benefits, in turn, are exogenous, being previously determined, either by a fixed amount or by a defined amount based on the individual's preretirement wages.

The second dimension, related to the funding method, distinguishes funded schemes from unfunded schemes. In funded schemes, the financing is provided through returns on financial market investments from the resources accumulated by individuals' contributions. In unfunded schemes, the financing is based on a PAYG structure, in which retirement benefits are financed by the current flow of contributions from the active population.

The third dimension has two characteristics, in which the term "actuarial" can designate both the macroeconomic context, referring to the long-term balance (viability) of the pension system, and the microeconomic context, regarding the match between contributions and benefits at the individual level.

In the context of this classification, according to Lindbeck (2006), NDC schemes are quasiactuarial schemes, that is, they are DC unfunded schemes. Therefore, they have exogenous contribution rates (hence endogenous retirement benefits). Contributions accumulated by individuals during working life are recorded into individual accounts only for accounting purposes instead of being invested in the financial market. In addition, the retirement benefits are financed on a PAYG basis.

\section{The Generic NDC Scheme}

Palmer (2006) formalizes a generic NDC scheme, which has the individual accounts as its central component. As it is configured in terms of nominal values, neutrality about inflation is adopted, so that the whole discussion takes place around real values.

\subsection{The Notional Capital}

According to the generic NDC scheme, the notional capital $K_{i, T}$, in the $T$-th period $t$, for an individual $i$ is determined by:

where:

$$
K_{i, T}=\sum_{t=1}^{T} c w_{i, t} I_{t}
$$

$c=$ contribution rate;

$w_{i, t}=$ individual wage (or earning) in period $t$;

$c w_{i, t}=$ individual contribution in period $t$;

$I_{t}=$ accumulated index in period $t$, calculated from the internal rate of return $\alpha_{n}$. 
This index is defined by:

$$
I_{t}=\prod_{\substack{n=t \\ I_{T}=1}}^{T-1}\left(1+\alpha_{n}\right),
$$

The notional capital in the $T$-th period $t$ is, therefore, the total sum of the individual's contributions up to the $T$-th period $t$. Further, for each of these contributions the index $I_{t}$ is applied, which represents the accumulated internal rate of return, from period $t$ to the period preceding the $T$-th period $t$, that is, $T-1$.

\subsection{The Annuity}

The annuity $P_{j, \tau}$, which is the retirement benefit, initiated in period $\tau$ for the retired individual $j$, is represented by:

$$
P_{j, \tau}=\frac{K_{j, \tau-1}}{G\left[L E_{\kappa_{j}, \tau}, \alpha\left(L E_{\kappa_{j}, \tau}\right)\right]},
$$

where:

$K_{j, \tau-1}=$ total notional capital for the retired individual $j$ in the period preceding the retirement starting period;

$\kappa_{j}=$ birth cohort of the retired individual $j$;

$L E_{\kappa_{j}, \tau}=$ average life expectancy for the retired individual $j$ from the birth cohort $\kappa_{j}$ in period $\tau$;

$\alpha\left(L E_{\kappa_{j}, \tau}\right)=$ internal rate of return specifically computed for a determined birth cohort $\kappa_{j}$ in period $\tau$;

$G\left[L E_{\kappa_{j}, \tau}, \alpha\left(L E_{\kappa_{j}, \tau}\right)\right]=$ annuity factor computed according to the average life expectancy $L E_{\kappa_{j}, \tau}$ and the internal rate of return $\alpha\left(L E_{\kappa_{j}, \tau}\right)$.

The annuity factor applied in formula (3) is defined by:

$$
G\left[L E_{\kappa_{j}, \tau}, \alpha\left(L E_{\kappa_{j}, \tau}\right)\right]=\frac{\sum_{x=y_{j, \tau}}^{\omega_{\kappa_{j}}}\left[\left(1+\alpha\left(L E_{\kappa_{j}, \tau}\right)\right)^{-\left(\omega_{\kappa_{j}}-x\right)} \times l_{x, \kappa_{j}}\right]}{l_{y_{j, \tau}, \kappa_{j}}}
$$

where:

$y_{j, \tau}=$ retired individual's $j$ age in period $\tau$;

$\omega_{\kappa_{j}}=$ last age at which there are living individuals belonging to the birth cohort $\kappa_{j}$; 
$l_{x, \kappa_{j}}=$ number of living individuals at age $x$ belonging to the birth cohort $\kappa_{j}$;

$l_{y_{j, \tau}, \kappa_{j}}=$ number of living individuals at age $y_{j, \tau}$ (retired individual's $j$ age in period $\tau$ )

belonging to the birth cohort $\kappa_{j}$.

Further, it should be analyzed some aspects of the estimated values of average life expectancy and the internal rate of return.

In principle, men and women have different values for average life expectancy. However, in countries where the NDC scheme was introduced, the annuity is calculated using unisex life expectancy, that is, the same average life expectancy for both sexes. This characteristic creates an explicit redistribution between those who survive less (usually men) to those who survive more (usually women).

In addition, the internal rate of return for the period of retirement benefits disbursement is only known after calculating the annuity. This means that, in practice, a rule to determine how $\alpha\left(L E_{\kappa_{j}, \tau}\right)$ enters formula (3) is required.

A procedure would be to adopt any reasonably close value for the expected internal rate of return. This requires a second rule to deal with the deviation between the current value of $\alpha\left(L E_{\kappa_{j}, \tau}\right)$ and the value used at the time of the annuity calculation. A convenient method would be to adjust the annuity, for example, annually using the difference presented in the deviation, such a way that if the current internal rate of return is lower than the rate used at the time of calculation, a negative correction is applied and vice versa.

An alternative to include $\alpha\left(L E_{\kappa_{j}, \tau}\right)$ in the annuity calculation would be to index annually by the internal rate of return, that is, by a real indexation with the current value of $\alpha_{t}$.

\subsection{The Internal Rate of Return and the Financial Balance}

The internal rate of return is the rate required for assuring pension system financial balance, a state in which the present value of the system's assets in period $t$, represented by $\operatorname{PV}\left(A_{t}\right)$, is equal to the present value of the liability computed in the same period, indicated by $\operatorname{PV}\left(L_{t}\right)$, that is:

$$
\operatorname{PV}\left(A_{t}\right)=\operatorname{PV}\left(L_{t}\right)
$$

In general, the present value of an asset (or a liability) is the current value of future cash flows discounted at a certain rate, called discount rate (Jordan, Ross and Westerfield, 2010). It can also be understood as the single amount at zero time equivalents to all future revenue (in the case of assets) or payment (in the case of liabilities) flows, assuming that the time value of money is determined by a discount rate (Promislow, 2015).

Returning to the interpretation of equation (5), it can be seen in Palmer (2006) and Serrano (2015) that the liability of a pension system based on NDC scheme in period $t$ is the sum of all liabilities to individuals who participate in the pension system, both active individuals and retired individuals. Thus, specifically to the generic NDC scheme, the present value of the liability in period $t$ is expressed by: 


$$
\operatorname{PV}\left(L_{t}\right)=\sum_{i=1}^{\psi} K_{i, t}+\sum_{j=1}^{\varphi} \operatorname{PV}\left(P_{j, \tau, t}\right)
$$

where:

$\psi=$ total number of active individuals in period $t$;

$\varphi=$ total number of retired individuals in period $t$;

$K_{i, t}=$ individual's $i$ notional capital in period $t$. It represents the liability to the active individual $i$ in period $t$;

$\operatorname{PV}\left(P_{j, \tau, t}\right)=$ present value of the annuity in period $t$ for individual $j$ which retired in period $\tau$.

It represents the liability to the retired individual $j$ in period $t$;

$\operatorname{PV}\left(P_{j, \tau, t}\right)$, according to Settergren (2001), is defined by:

$$
\operatorname{PV}\left(P_{j, \tau, t}\right)=\left\{\begin{aligned}
P_{j, \tau, t} \times G\left[L E_{\kappa_{j}, t}, \alpha\left(L E_{\kappa_{j}, t}\right)\right], & t \geq \tau \\
0 & , t<\tau
\end{aligned}\right.
$$

Equation (7) shows that the present value of the annuity in period $t$ for individual $j$ who retired in period $\tau$, given that $t \geq \tau$, is the product of his annuity by the annuity factor corresponding to the birth cohort $\kappa_{j}$, both values positioned in period $t$ (Serrano, 2015).

On the other side, the present value of the asset in period $t$ according to the generic NDC scheme is the present value of the flow of future contributions from all active individuals in period $t$ (called contribution asset) added to the reserve fund, expressed by:

$$
\operatorname{PV}\left(A_{t}\right)=C A(t)+\text { Reserve Fund } t
$$

where:

$$
C A(t)=T D_{t} \times \sum_{i=1}^{\psi} c w_{i, t}
$$

Concerning the contribution asset, Settergren and Mikula (2006) demonstrate that in a steady-state, characterized by constant rates of mortality and population growth, the total amount of contributions is equal to the total amount of retirement benefits paid. Under this condition, the net present value of a PAYG pension system is zero, considering that the liabilities are equivalent to an implicit asset (the contribution asset). In this case, it is not necessary to set up a reserve fund for covering liabilities.

The reserve fund, in turn, aims to absorb demographic fluctuations that may affect the system financial balance. According to Palmer (2006), fund resources and disbursement mechanisms will depend on the system design.

In equation (9), $T D_{t}$ represents the turnover duration of the contribution asset in period $t$. The turnover duration is a density function, developed and described in Settergren and Mikula 
(2006). It is shown that in a steady-state, the ratio of liabilities to total contributions of a PAYG pension system is equal to the difference between the average age of retired individuals and the average age of active individuals, weighted by retirement benefits and wages, respectively. This difference would be a measure of the pension liability duration, called turnover duration.

Palmer (2006) defines the turnover duration of a contribution asset as the average time that a monetary unit remains in the pension system. Thus, the turnover duration in period $t$ can be expressed by (Settergren and Mikula, 2006):

$$
T D_{t}=\mathrm{A}^{P} \varphi_{t}-\mathrm{A}^{w} \psi_{t}
$$

where:

$\mathrm{A}^{P} \varphi_{t}=$ average age of retired individuals in period $t$, weighted by retirement benefits.

$\mathrm{A}^{w} \psi_{t}=$ average age of active individuals in period $t$, weighted by wages.

Palmer (2006) explains that in the generic NDC scheme, both the accounts of active individuals during the contribution period and the accounts of retired individuals converted into annuities are subject to the same internal rate of return in a given period $t$.

It is observed that in a steady-state, defined by a fixed distribution of wages and individuals' ages and fixed mortality rates for each age, an internal rate of return $\alpha_{t}$ for the NDC scheme based on the instantaneous growth rate in the contributory base is sufficient to maintain the pension system financial balance. This instantaneous rate is determined by the productivity growth rate $g_{t}$, and the workforce growth rate $\lambda_{t}$.

In practice $\lambda_{t}+g_{t}$ is not sufficient to assure system financial balance, mainly because of different distributions of contribution and retirement benefit flows can affect the capacity to maintain the balance between asset and liability, damaging the pension system instant liquidity.

In this sense, if the time spent in the system of a monetary unit in period $t$, so that $T D_{t}$ is greater or less than $T D_{t-1}$, then the present value of the asset, according to the expressions (8) and (9), would change uniquely as a result of this difference. Therefore, this variation would constitute a component of the internal rate of return, in which:

$$
\rho_{t}=\left[\frac{\mathrm{PV}\left(A_{t}\right)}{\mathrm{PV}\left(L_{t}\right)}\right]-1
$$

Thus, in the generic NDC scheme, the internal (real) rate of return is given by:

$$
\alpha_{t}=g_{t}+\lambda_{t}+\rho_{t}
$$

where $\boldsymbol{\rho}_{\boldsymbol{t}}$ is an adjustment of the instantaneous growth rate in the contributory base, $\boldsymbol{g}_{\boldsymbol{t}}+\boldsymbol{\lambda}_{\boldsymbol{t}}$, assuming a non-steady state. 


\subsection{The Reserve Fund}

In NDC scheme, the occurrence of fluctuations between large and small birth cohorts suggests that, keeping the other variables constant (fixed distribution of wages and individuals' ages and fixed mortality rates for each age), contributions of large cohorts should be provisioned and liquidated when individuals belonging to it become retired.

There will be a tendency of pension system financial unbalance if this is not done. On occasions when the liability is greater than the asset $\left(L_{t}>A_{t}\right)$, the value resulting from the difference $L_{t}-A_{t}$ represents the necessary amount to be constituted in the reserve fund in period $t$.

In this sense, the main purpose of the reserve fund is to collect and disburse resources from demographic fluctuations, to prevent system deficits. For this, the rate of return applied to this fund must be at least equal to the internal rate of return $\alpha_{t}$.

The reserve fund can also be used for other purposes, such as, for example, financing minimum retirement benefits to individuals who have not reached a sufficient contribution level to obtain a retirement benefit on which they can live on. For this, revenues from general taxes and/or a special contribution rate could be transferred to the reserve fund, to finance these benefits.

\subsection{The Automatic Balancing Mechanism}

In practice, if NDC schemes implemented in the countries somehow deviate from the generic NDC scheme, equation (11) consequently encompasses all these deviations.

The most common types of deviation concerning the generic NDC scheme are: (1) use of mortality rates different from the current ones to compute the average life expectancy applied in the annuity calculations, situation in which the cost with retirement benefits may be higher if individuals have a longer-than-expected standard of longevity at the time of the initial benefit calculation; (2) pension system indexation only by the productivity growth rate $g_{t}$, or by the productivity growth rate plus the workforce growth rate, $g_{t}+\lambda_{t}$, instead of $g_{t}+\lambda_{t}+\rho_{t}$; and (3) reserve fund indexation by rates of return different from those applied in notional accounts indexation.

Factors such as those described above can cause that in practice equation (11) yields:

$$
b_{t}=\left[\frac{\mathrm{PV}\left(A_{t}\right)}{\mathrm{PV}\left(L_{t}\right)}\right]-1
$$

where $b_{t}=\rho_{t}$ if the scheme is generic. Also, $b_{t}$ is the factor with which notional accounts and annuities need to be adjusted to assure pension system financial balance.

In an attempt to solve this issue, the Automatic Balancing Mechanism (ABM) is triggered as follows: if $\operatorname{PV}\left(A_{t}\right)<\operatorname{PV}\left(L_{t}\right)$, regardless of cause, there will be a reduction in the value of the internal rate of return $\alpha_{t}$ applied to notional accounts and annuities, to allow the system to return to a financial equilibrium state. Similarly, if $\operatorname{PV}\left(A_{t}\right)>\operatorname{PV}\left(L_{t}\right)$, there may be an increase in the rate, resulting in greater returns for the individuals' contributions and, consequently, greater retirement benefits.

Sweden, for example, to ensure pension system financial balance, adopts a similar mechanism to that presented by Palmer (2006). In case that the ratio between system assets and liabilities 
(balance ratio) is below 1, the Swedish ABM is activated, temporarily abandoning the system indexation by the income index, a measure based on the per capita wage growth rate (Könberg, Palmer and Sundén, 2006).

The rate of return applied to contributions and the indexation of retirement benefits starts being based on a new index, the balance index, which is established by multiplying the income index by the balance ratio. If the balance ratio exceeds 1 in the period in which the ABM is being executed, the balance index will continue to be used until it reaches the same level as the income index. When this situation occurs, ABM is untriggered and the Swedish pension system is indexed again by the income index (Settergren, 2001).

\section{NDC in Europe}

This section briefly presents some experiences of European countries, which implemented the NDC scheme in their public pension systems.

\subsection{NDC in Sweden}

The Swedish pension reform dates back to 1992 when the Parliamentary Working Group on Pensions published an outline of the NDC reform, which was later legislated in 1994 (Könberg, Palmer and Sundén, 2006; Chłoń-Domińczak, Franco and Palmer, 2012).

The pre-reform in the Swedish public pension system combined a flat-rate universal benefit with an earnings-related benefit, which was based on an individual's 15 years of highest earnings, requiring 30 years of contribution for a full pension. This earnings-related benefit replaced 60 per cent of the average earnings of the highest 15 years up to a ceiling.

The old system had several problems, however. There was no link between benefits and the real wage growth of the working population, exposing the system to the risk of a declining labour force. There was no response to demographic changes, although at the time of the reform, the share of individuals 65 years and older in the population was expected to be 20 per cent in 2025 .

The connection between contributions and benefits was weak because contributions were paid on all earnings from age 16 until retirement, while benefits were based only on the 15 years with the highest earnings. In addition, the deep recession in which Sweden went into in 1992 affected the contribution base, which had fallen by 10 per cent in 1994.

In this context, the 1994 legislation transformed Sweden's public pension system from a defined benefit pay-as-you-go (DB-PAYG) scheme into a system composed by NDC scheme and financial (funded) defined contribution (FDC) scheme.

The total contribution rate of the new public Swedish pension system is 18.5 per cent of earnings: 16 per cent credited to the notional account and 2.5 per cent credited to the FDC scheme. Noncontributory rights such as income from unemployment, sickness, disability, and other social insurance programs are financed with general tax revenues.

The main part of the new pension system is the NDC component. Individual account balances grow with annual contributions and the rate of return on the account. This rate is determined by the per capita wage growth, differently from the generic NDC scheme. 
The minimum retirement age was 61 until 2019. As of 2020, this age is 62 . At retirement, annual benefits are calculated by dividing the balance in the notional account by an annuity divisor. The divisor is determined by average life expectancy at retirement for a given cohort at age 65 with a real rate of return of 1.6 per cent. If the individual retires before age 65 , the average life expectancy is updated until this age (Könberg, Palmer and Sundén, 2006; Swedish Pensions Agency, 2020).

Analyzing the impact of the 2008 economic crisis, Könberg, Palmer and Sundén (2006) discuss that unlike other countries such as Italy, Latvia and Poland, Sweden had an explicit NDC reserve fund. In 2008, the value of the fund fell with the general decline in the global equity market (Chłoń-Domińczak, Franco and Palmer, 2012).

As a result, ABM mechanism was triggered, reducing worker's accounts and pensioner's benefits (Könberg, Palmer and Sundén, 2006). After 2009, the system has been recovered from the crisis, with positive balance ratio (ratio between assets and liabilities) until 2019, except in 2012 when it slightly dropped under 1 again (Swedish Pensions Agency, 2014, 2020).

\subsection{NDC in Italy}

The reform of the public pension system in Italy began with the Amato reform in 1992, when about a quarter of prospective public sector pension liabilities were cancelled. The government introduced some parametric changes: increased the standard retirement age by five years; shifted benefit indexation from wages to prices; and linked benefits to lifetime earnings rather than to the average of the last five years of employment for private-sector employees and the final wage for central government employees (Franco and Sartor, 2006; Chłoń-Domińczak, Franco and Palmer, 2012).

A second major reform was introduced in 1995 with the implementation of the NDC scheme, in which account values at retirement are converted into an annuity using conversion coefficients based on an estimate of life expectancy. According to Franco and Sartor (2006), this second reform aimed at equalizing the yields of the contributions paid by all workers of the same sex and the same pension cohort, removing favourable treatment previously granted to workers with dynamic careers.

Both reforms were justified by three main factors. First, pension expenditure had increased from 5.0 per cent of GDP in 1960 to 14.9 per cent in 1992 and it was expected to increase further and get close to 25.0 of GDP by 2030 . Second, the lack of an actuarial correlation between the size of the benefit and the age of retirement was an incentive for the earliest possible retirement. Finally, the reference period for calculating pensionable earnings worked in favour of those whose earnings had risen most rapidly toward the end of their careers.

In the Italian NDC scheme, old-age retirement benefits are related to the contributions paid over the whole working life and to the age of the individual at retirement. The benefits are determined by multiplying the balance of the notional individual account by an age-related conversion coefficient. Contribution rates are not the same for all workers: 33 per cent for employees and 20 per cent for self-employed. These contributions are capitalized at a five-year moving average of GDP growth.

Additional changes were introduced over the years. Starting from January 2012, NDC accounts were created even for older workers not previously covered by the NDC scheme; the 
statutory retirement age was set at 66 years age from 2012 for all workers except for women in the private sector, for whom it gradually increases to 66 beginning in 2018; and the eligibility requirements for seniority pensions were significantly tightened.

For the statutory old-age pension, from 1 January 2019, in addition to at least 20 years of contributions, the individual retirement age is 67 years for all categories of workers (European Commission, n.d.-a).

Franco and Sartor (2006) and Chłoń-Domińczak, Franco and Palmer (2012) explain that although the rapid introduction of NDC in 1995 represented a striking development in Italian pension policy, the government had failed to conduct an open and extensive debate with implications on the technical and political sides. Further, short-term political considerations led to an extremely slow transition from the old to the new system, avoiding immediate cuts in replacement rates and affecting the macroeconomic sustainability of the new rules.

Concerning the impact of the 2008 economic crisis, Chłon-Domińczak, Franco and Palmer (2012) mention that in Italy changes introduced to increase the retirement age automatically adjusted to longevity was a way of offsetting the impact of the crisis, although there was no discussion evolving the influence of the crisis in NDC since the number of NDC pension being paid was very small.

\subsection{NDC in Latvia}

Latvia developed and passed its own NDC in 1995 and implemented it in January 1996. The Latvian reform promised stability in the face of demographic and economic fluctuations. In addition, it provided an adequate average benefit level for career workers and guaranteed an acceptable minimum pension standard (Palmer et al., 2006; Chłoń-Domińczak, Franco and Palmer, 2012).

The moving toward establishing a market economy and democratic institutions had led the Latvian economy to collapse, after its independence in 1990. At the time of the 1995 reform, there was still no sign that the economy would rebound into sustained growth. Unemployment was high, and many workers did not have full-time jobs.

As a result, from 1991 to 1995, the contribution base had declined by almost 50 per cent, and, by the end of 1995 , about 1.5 persons were receiving a pension per contributor. Therefore, there were too many people receiving benefits and too few paying contributions.

In addition, the rules of the old Latvian public pension system were not appropriate for a market setting and an ageing population. There was no link between contributions and benefits, and no actuarial adjustment for postponed retirement; in other words, there were weak incentives to pay contributions and no incentives to postpone retirement past the minimum retirement age.

The Latvian public pension system consists of two components: the NDC scheme implemented in 1996 and the FDC scheme introduced in 2001. The NDC scheme covers all persons living and working in Latvia from age 15, including the self-employed and farmers.

The contribution rate on earnings was set at 20 per cent from January 1, 1996, but according to the initial legislation, this percentage would be gradually reduced until 2010, when the overall contribution rate (of still 20 per cent) would be split evenly between NDC and FDC. However, the 2008 economic crisis showed that this commitment was unaffordable. The government's response was to legislate, in 2009, a new split of 14 per cent for NDC and 6 per cent for FDC, starting in 2012. 
Accumulated notional pension capital is determined by contributions, paid on all earnings up to a ceiling, and during whole working life. The rate of return on notional capital is equal to the growth of contributions, reflecting the growth of productivity, the wage rate, changes in fertility, the net migration of working-age persons, and the gradual transition from the informal to the formal economy.

The retirement benefit can be claimed in 2019 at any time from the age of 63 years and 6 months for both men and women with a minimum of 15 years of contribution. The retirement age will reach 65 years on 1 January 2025, with a minimum of 20 years of contribution (European Commission, n.d.-b).

The retirement benefit in the Latvian NDC scheme is calculated dividing the accumulated lifetime notional pension capital by the cohort unisex life expectancy at retirement. Life expectancy values are based on mortality projections, which are prepared and analyzed by an official committee of Latvian demographic experts.

\subsection{NDC in Poland}

The Polish public pension reform process began in 1996. The reform proposal, which included the transition to NDC and FDC schemes, was published at the beginning of 1997. The new pension system started in 1999 replaced all previous legislation on old-age pension for the majority of the working population (Chłoń-Domińczak and Góra, 2006; Chłoń-Domińczak, Franco and Palmer, 2012).

It was verified that the ageing population was one of the most important reasons for the reform. Together with the decreasing in fertility rates, they explain that in the period between 1998 and 2002, the life expectancy for both men and women at 60 and 65 increased by almost a year.

The second most important reason for the reform was the drop in employment, which affected the financing of the pension system. From the early 1990s, the transition from the planned to the market economy contributed to disorganize the Polish labour market, disintegrating the infrastructure for collecting contributions and taxes.

The new Polish public pension system is composed of NDC and FDC schemes. With the reform, the contribution rate on wages is divided into 12.22 per cent for the NDC scheme and 7.3 per cent for the FDC scheme. The rate of return applied to NDC accounts is based on the growth of the sum of paid contributions. At retirement, an annuity is calculated based on the accumulated notional capital and the life expectancy at retirement age. The current minimum retirement ages are 60 for women and 65 for men (Chłoń-Domińczak and Góra, 2006; European Commission, n.d.-c).

Chłoń-Domińczak, Franco and Palmer (2012) explain that although Poland was one of the few countries that went through the 2008-2009 recession with positive real economic growth, the economy slowed, worsening the public financing. The contribution revenues declined and the Social Insurance Fund had to seek external funding from commercial banks to cover the deficit. As a result, from 2011, the government reduced the proportion of contributions for the FDC scheme and created two parallel NDC-type accounts, with different rules of indexation and inheritance. 


\subsection{NDC in Norway}

The Norwegian reform in its public pension system began in 2001 when the government appointed a Pension Commission, which included representatives from the political parties. After years of discussions, the new system was approved by the parliament in 2009 (Christensen et al., 2012).

Similar to most of the member countries of the OECD, projections for the Norwegian old pension system reveal that the country would face substantial challenges in the coming decades because of the expected ageing of the population. The population above 67 was expected to more than double by 2050 , leading to a strong increase in pension expenditure.

In addition, in the old rules, large groups were covered by the collectively bargained early retirement scheme (AFP), in which benefits could be claimed from age 62 to age 66. This scheme was not actuarially neutral, since the size of the annual AFP pension was almost independent of the retirement age between ages 62 and 66. In addition, there was no actuarial adjustment for persons postponing retirement until after age 67.

In the new Norwegian public pension system, individuals between ages 13 and 75 contribute with 18.1 per cent of the earnings up to a ceiling. These contributions (called pension entitlements) are registered on individual notional accounts and are adjusted each year in line with wage growth. At the time of retirement, the annual pension is calculated by dividing the accumulated pension entitlements by an annuity divisor that reflects remaining life expectancy and a fixed rate of return of 0.75 per cent.

The retirement age was fixed at age 67 and it was possible to postpone retirement until age 70, before 2011. Beginning in 2011, flexible retirement was introduced for the 62-75 age group, base on actuarial neutrality. In addition, it is possible to combine retirement and work, where the individual can withdraw $20,40,50,60$ or 80 per cent of a full pension.

Two points can cause some disequilibrium in the new Norwegian pension system, although the positive points described above. First, pension entitlements are accumulated only up to a ceiling on annual income. According to Christensen et al. (2012), this weakens the link between benefits and lifetime earnings, especially in higher earnings above the ceiling. Second, the new pension system is still part of general public finances, in which the government assumes both the risk of a declining working-age population and the longevity risk caused by the chance of underestimating life expectancy values.

\section{Conclusions}

This article discussed the main characteristics and concepts related to NDC schemes. In addition, it was briefly explained the NDC experience of five European countries, Sweden, Italy, Latvia, Poland and Norway, as a pension system alternative.

It was observed that the NDC schemes originate from the composition of formulations present in Buchanan's scheme, in the PSA scheme, and in the French and German point systems. Also, the sharing of ideas and discussions between experts and politicians who addressed this topic and the series of reforms that redesigned pension systems in Europe in the 1990s contributed to materialise the idea of NDC schemes, as they are currently known. 
It has been shown that NDC is a defined contribution PAYG scheme, classified as quasiactuarial. This implies that the retirement benefits have a direct correspondence with the contributions made over the individual's working life, and these benefits are financed by contributions from the active population. Contributions, in turn, form an individual account only for accounting purposes, so that deposits in that account are not invested in the financial market.

Regarding the generic form, the main NDC components are the notional capital, the annuity and the internal rate of return. The notional capital is the total sum of the individual's indexed contributions during the working life. The annuity, which is the retirement benefit, is equivalent to the ratio between the notional capital and the annuity factor, which considers the average life expectancy for the individual at retirement age.

The internal rate of return, composed of the productivity growth rate, the workforce growth rate and an adjustment resulting from the ratio between the system's assets and liabilities in the same period, is used in the annuity and the notional capital indexation.

Just as the average life expectancy is utilized to measure the present value of liabilities to retired individuals, which together with the notional capital of active individuals compose the system's liabilities, the turnover duration is a measure used in estimating the present value of the flow of future contributions from active individuals, which, added to the reserve fund, forms the system's asset.

It was found that the generic NDC scheme has two elements that promote pension system financial balance: the reserve fund, which collects and disburses resources from demographic fluctuations and the $\mathrm{ABM}$, a mechanism that automatically decreases the internal rate of return in deficit situations, reducing notional capital and annuities.

Finally, analyzing the experiences of Sweden, Italy, Latvia, Poland and Norway, it was possible to conclude that the NDC reforms were not homogeneous, as well as the degree of closeness to the generic NDC scheme. This degree contributes to determining the extent of NDC as a pension system alternative.

Sweden was the first country in the world to implement the NDC scheme, and among the five, the unique to have an ABM mechanism. Italy passed a rapid reform but failed to conduct an open and extensive debate. In addition, the transition was extremely slow, which affected the macroeconomic sustainability of the new rules.

NDC reforms in Latvia and Poland were one of the outcomes of the transition from planned to a market economy. The 2008 economic crisis made negative impacts in both countries, mainly because they had a considerable part (more than in Sweden) of their pension systems compounded by FDC scheme, in addition to the NDC scheme.

Norway, the last country to implement NDC introduced flexible retirement ages with actuarial adjustments and benefits reflecting life expectancy, but the system continued to be part of general public finances, in which the government has to assume some demographic and longevity risks.

For further developments, it is important to analyze the social implications of NDC implementation, such as the impact on replacement rates, the impact of unemployment on the level 
of future retirement benefits and the impact of applying automatic mechanisms similar to the ABM on the pensioners' incomes.

\section{References}

[1] Boskin, M., Kotlikoff, L. J. and Shoven, J. (1985). Personal Security Accounts: A Proposal for Fundamental Social Security Reform, Policy Paper No. 63, Stanford, USA, Center for Economic Policy Research, Stanford University. DOI: 10.22004/ag.econ.244431.

[2] Buchanan, J. (1968). Social insurance in a growing economy: A proposal for radical reform. National Tax Journal, 21, 386-395.

[3] Chłoń-Domińczak, A. and Góra M. (2006). The NDC System in Poland: Assessment after Five Years. In R. Holzmann and E. Palmer (Eds.), Pension Reform: Issues and prospect for non-financial defined contribution (NDC) schemes (pp. 425-448). Washington, DC: World Bank. DOI: 10.1596/978-0-82136038-5.

[4] Chłoń-Domińczak, A., Franco, D. and Palmer, E. (2012). The First Wave of NDC Reforms: The Experiences of Italy, Latvia, Poland, and Sweden. In R. Holzmann, E. Palmer and D. Robalino (Eds.), Nonfinancial defined contribution pension schemes in a changing pension world: Vol. 1: Progress, Lessons, and Implementation (pp. 31-84). Washington, DC: World Bank. DOI: 10.1596/978-0-82138848-8.

[5] Christensen, A. et al. (2012). Pension Reform in Norway: Combining an NDC Approach and Distributional Goals. In R. Holzmann, E. Palmer and D. Robalino (Eds.), Nonfinancial defined contribution pension schemes in a changing pension world: Vol. 1: Progress, Lessons, and Implementation (pp. 129-154). Washington, DC: World Bank. DOI: 10.1596/978-0-8213-8848-8.

[6] Corrêa, C. (2018). Premissas atuariais em planos previdenciários: uma visão atuarial-demográfica. Curitiba, Brazil: Appris. ISBN: 978-8-54-731143-8.

[7] European Commission. (n.d.-a). Italy - Old-age benefits. Taken from: https://ec.europa.eu/social/main.jsp?catId=1116\&langId=en\&intPageId=4625.

[8] European Commission. (n.d.-b). Latvia - Old-age pension. Taken from: https://ec.europa.eu/social/main.jsp?catId=1117\&langId=en\&intPageId=4638\#: :text=In\%202019 \%2C\%20the\%20retirement\%20age,years\%20on\%201\%20January\%202025.

[9] European Commission. (n.d.-c). Poland - Retirement pensions. Taken from: https://ec.europa.eu/social/main.jsp?catId=1124\&langId=en\&intPageId=4726.

[10] Franco, D. and Sartor, N. (2006). NDCs in Italy: Unsatisfactory Present, Uncertain Future. In R. Holzmann and E. Palmer (Eds.), Pension Reform: Issues and prospect for non-financial defined contribution (NDC) schemes (pp. 467-492). Washington, DC: World Bank. DOI: 10.1596/978-0-82136038-5.

[11] Holzmann, R. (2017). The ABCs of nonfinancial defined contribution (NDC) schemes. International Social Security Review, 70, 53-77. DOI: 10.1111/issr.12142.

[12] Jordan, B., Westerfield, R. and Ross, S. (2010). Fundamentals of Corporate Finance. New York, USA: McGraw-Hill/Irwin. ISBN: 978-0-07-338239-5.

[13] Könberg, B., Palmer, E. and Sundén, A. (2006). The NDC reform in Sweden: The 1994 legislation to the present. In R. Holzmann and E. Palmer (Eds.), Pension Reform: Issues and prospect for non-financial defined contribution (NDC) schemes (pp. 449-466). Washington, DC: World Bank. DOI: 10.1596/9780-8213-6038-5. 
[14] Lindbeck, A. (2006). Conceptualization of Non-Financial Defined Contribution Systems. In R. Holzmann and E. Palmer (Eds.), Pension Reform: Issues and prospect for non-financial defined contribution (NDC) schemes (pp. 71-94). Washington, DC: World Bank. DOI: 10.1596/978-0-8213-6038-5.

[15] Lindbeck, A. and Persson, M. (2003). The Gains from Pension Reform. Journal of Economic Literature, 41, 74-112. DOI: $10.1257 / 002205103321544701$.

[16] Palmer, E. (2000). The Swedish pension reform model: Framework and issues, Social protection discussion paper, No. 12, Washington, DC, World Bank.

[17] Palmer, E. (2006). What is NDC? In R. Holzmann and E. Palmer (Eds.), Pension Reform: Issues and prospect for non-financial defined contribution (NDC) schemes (pp. 17-34). Washington, DC: World Bank. DOI: 10.1596/978-0-8213-6038-5.

[18] Palmer, E. et al. (2006). NDC Strategy in Latvia: Implementation and Prospects for the Future. In R. Holzmann and E. Palmer (Eds.), Pension Reform: Issues and prospect for non-financial defined contribution (NDC) schemes (pp. 397-424). Washington, DC: World Bank. DOI: 10.1596/978-0-82136038-5.

[19] Promislow, D. (2015). Fundamentals of Actuarial Mathematics. Toronto, Canada: John Wiley and Sons. ISBN: 978-1-118-78246-0.

[20] Serrano, F. A. (2015). Gestão de sistemas de pensões em contas nocionais: arquitetura e gestão de riscos (Doctoral thesis, Évora University, Portugal). Taken from: http://dspace.uevora.pt/rdpc/handle/10174/17513.

[21] Settergren, 0. (2001). The Automatic Balancing Mechanism of the Swedish Pension System, Working Papers in Social Insurance 2001:2, Stockholm, Sweden, The National Insurance Board.

[22] Settergren, O. and Mikula, B. D. (2006). The rate of return of pay-as-you-go pension systems: A more exact consumption-loan model of interest. In R. Holzmann and E. Palmer (Eds.), Pension Reform: Issues and prospect for non-financial defined contribution (NDC) schemes (pp. 117-148). Washington, DC: World Bank. DOI: 10.1596/978-0-8213-6038-5.

[23] Swedish Pensions Agency. (2014). Orange Report - Annual Report of the Swedish Pension System 2013. Stockholm: Author. Taken from: https://www.pensionsmyndigheten.se/otherlanguages/englishengelska/englishengelska/ publications0. ISSN: 1654-126X.

[24] Swedish Pensions Agency. (2020). Orange Rapport 2019 - Pensionssystemets årsredovisning. Stockholm: Author. Taken from: https://www.pensionsmyndigheten.se/statistikochrapporter/Rapporter/arsredovisningar. ISSN: 1654-126X.

[25] Valdés-Prieto, S. (2000). The Financial Stability of Notional Account Pensions. The Scandinavian Journal of Economics, 102, 395-417. DOI: 10.1007/978-3-030-29019-1.

[26] World Bank. (2006). Pension Reform: Issues and Prospects for Non-Financial Defined Contribution (NDC) Schemes. Washington, DC: Author. DOI: 10.1596/978-0-8213-6038-5.

[27] World Bank. (2012). Nonfinancial defined contribution pension schemes in a changing pension world: Vol. 1: Progress, Lessons, and Implementation. Washington, DC: Author. DOI: 10.1596/978-0-82138848-8. 